\title{
Exploring the therapeutic potential of marine-derived bioactive compounds against COVID-19
}

\author{
Rachana Singh $^{1}$ (D) Niketa Chauhan ${ }^{1} \cdot$ Mohammed Kuddus $^{2}$ \\ Received: 22 July 2021 / Accepted: 18 August 2021 / Published online: 2 September 2021 \\ (C) The Author(s), under exclusive licence to Springer-Verlag GmbH Germany, part of Springer Nature 2021
}

\begin{abstract}
The ocean is the most biodiverse habitat of various organisms. The organisms surviving in the harsh conditions of the ocean consist of several spectacular properties and produce bioactive compounds of pharmacological importance. These compounds are effective even in small quantities with various immunomodulatory qualities such as antioxidant and anti-inflammatory properties. Though the vaccines for COVID-19 are developed, and drug development is also in progress, but till now no effective drug is available for this deadly virus. Researchers are mining the huge data of bioactive compounds to develop the specific drug for COVID-19. The use of the repurposed drugs is challenging against the rapidly mutating virus with variable symptoms and mode of transmission. This review is an attempt to compile all the spattered data of marine-derived bioactive compounds with antiviral properties and to explore their therapeutic potential against COVID-19.
\end{abstract}

Keywords Bioactive compounds $\cdot$ Marine-derived $\cdot$ COVID-19 $\cdot$ Antiviral $\cdot$ Halobiont $\cdot$ Sponge $\cdot$ The therapeutic potential

\section{Introduction}

SARS-CoV-2 emerged as an outbreak in Wuhan, China, and soon it spread to all parts of the world. Contamination is speeded by infected individuals who traveled the country; furthermore, lack of awareness about this new virus which has symptoms similar to common flu also enhances the spread. The spread of COVID-19 was so rapid that it infected nearly 1 million people within 3 months, and 50,000 deaths have been reported. Very soon, the infection rate increased tenfold with 10 million people reported and more than 500,000 deaths. Studies suggest that the transmission by asymptomatic people is the major factor of the high infection rate of COVID-19, and that was estimated up to $40 \%$ (http:// www.niaid.nih.gov/diseases-conditions/covid-19). Another disturbing fact about this virus is that different mutants of

Responsible Editor: Lotfi Aleya

Rachana Singh

rsingh1@1ko.amity.edu

1 Amity Institute of Biotechnology, Amity University Uttar Pradesh, Lucknow, Uttar Pradesh 226028, India

2 Department of Biochemistry, College of Medicine, University of Hail, Hail, Saudi Arabia the virus are emerging; the changes in invariants were observed basically in the spike protein of the coronavirus. New variants are spreading quickly leading to new cases with more pace.

This disease has drawn the attention of scientists throughout the world, and various studies have been initiated to understand the virus and how to control its spread and manage the virus. Researchers are investigating approaches to treat SARS-CoV-2 diseases by attempting to produce drugs, therapeutics, and vaccines. Some of the repurposed drugs can stop the entry of the virus to cells, some can slow down the immune response, and some prevent the replication process of the virus. Considering the progressing COVID-19 pandemic brought by it, assigned as Severe Acute Respiratory Syndrome Coronavirus-2 (SARS-CoV-2), sources are being made for creating productive treatment alternatives to handle the infection.

The SARS-CoV-2 has been distinguished as an enveloped, single-stranded, positive-sense RNA virus that belongs to the group Betacoronavirus of family Coronovirdae. Other genera of the family are alpha coronavirus, delta coronavirus, and gamma coronavirus) (Behl et al. 2020; Gorblimey et al. 2020, Singh et al. 2021, Woo et al. 2010). It is essentially known to infect the upper respiratory tract and digestive tract (Zhu et al. 2020). Further, this virus consists of different underlying proteins, spike glycoprotein, non-structural proteins 
such as helicase, protease, protease, and RNA-subordinate RNA polymerase, and some extra proteins are also encoded by the SARS-CoV-2 genome. Structure analysis showed that the spike glycoprotein is crown-shaped which leads to the origin of the name "the corona" (derived from the Latin word for crown). While spike protein is present on the exterior surface (membrane) of the virus, viral capsid and single-stranded RNA genome are present inside the virus. The entry of a virus inside the host cell initiates when the glycoprotein present on the surface of the virus binds to the receptor present in the cell. The virus enters the hearts and kidneys by binding with the blood vessels and in the lungs by binding with the epithelial cells and intestine ( $\mathrm{Xu}$ et al. 2020). This glycoprotein is responsible for the interaction of viruses and receptors, present on the host cell. Since this spike glycoprotein is a basic necessity for the passage of this virus into the host cells, several new investigations are centered around this primary protein. It has been additionally reasoned that the previously stated five proteins also emerged as appealing focuses for antiviral examinations against previous infections, i.e., SARS and MERS (Middle East respiratory syndrome) (Zumla et al. 2016).

The SARS-CoV-2 pandemic created an emergency crisis circumstance that makes it crucial to discover new treatments and activities targeted at diminishing the virus spread followed by infection and discovering new remedial applications for existing and affirmed drugs that permit its fast treatment of new infection. Similarly, given the progressively better information on the viral mechanism in human cells, it is vital to look for new compounds and consolidate treatments that might be useful in the prophylaxis and therapeutics of COVID-19.

Marine-derived bioactive compounds could be a decent choice/alternative against SARS-CoV-2. The utilization of marine organisms to prevent or treat various infections has been done for a long time and is still being done in treating various complex diseases such as cancer, various viral diseases, and malaria. These compounds have the potential of having pharmacological activities such as anti-tumor, antiviral, antioxidant, anti-microbial, and anti-coagulant (Bhatt et al. 2020) (Fig. 1).

\section{Marine-derived antiviral compounds}

As the antiviral compounds derived from marine sources have gained attention, the advancement and innovation in techniques used in the marine ecosystem and extraction will facilitate the investigation of the marine bioactive derivatives that have huge applications in pharmacology, and the potential to be developed as a future drug. In the past 30 years, the marine sources and their biological activities are explored well, and a large number of unique compounds and their metabolites have been identified, and some have been utilized as anticancer and antiviral, etc. (Arif et al. 2004) (Table 1).

In the marine ecosystem, many bacteria striving in habitats with extreme pressure and temperature, along with high $\mathrm{H}_{2} \mathrm{~S}$ and heavy metal concentrations, yield exopolysaccharides as an approach for growth and attachment to solid surfaces and their survival in extreme conditions (Vincent et al. 1994). Marine fungi and their metabolites are perceived for their promising bioactive compounds in the last few years. A portion of these metabolites gives marine fungi the advantage to survive extreme conditions, substrate competence, and avert dangers (Gallo et al. 2004). Since, most of the fungi live in symbiotic association with other marine microbes such as algae, sponges, and other invertebrates (Duarte et al. 2012), fungi metabolites are also affected by the source from where they are being isolated. Various studies revealed the association of marine-derived bioactive compounds with different biological functions such as anticancer, antiviral, anti-plasmodial, and anti-diabetic properties along with other pharmaceutical activities like inhibition of cell cycle, inhibition of kinase and phosphatase, antioxidant, neuritogenic, and anti-inflammatory (Hart 1999; Abdel-Lateff et al. 2003; Daferner et al. 2002; Gautschi et al. 2004; Tziveleka et al. 2003).

The marine corals and sponges are considered an important library of potential future drugs. In the 1950s, nucleosides, spongothymidine, and spongouridine were discovered from the marine sponge Cryptotethia crypta (Bergmann and Feeney 1950, 1951); since then, approximately 15,000 marine products were isolated from sponges which later on reported for the discovery of 5300 different other products. The extraction of new compounds is continued which are originated from marine sponges. Because of their huge biodiversity, sponges are considered as "gold mine" (Sipkema et al. 2005) (Fig. 2).

\section{Marine bioactive compounds for SARS-CoV-2}

The order Scleractinia of class Anthozoa is found exclusively in the marine ecosystem. This order comprising stony corals is the most biodiverse and dynamic. They can be solitary, but in the colonial form they harbor vast communities of beneficial microbes; this assemblage of host coral and its remarkable symbiotic relationship with unicellular organisms known as zooxanthellae and an array of microorganisms form the "coral halobiont". Associated organisms can be bacteria, fungi, complemented by unicellular endosymbionts, zooxanthellae, which are microscopic photosynthetic dinoflagellate algae belonging to the genus Symbiodinium invading and then residing inside of coral tissue (Table 2).

Zahran et al. (2020) worked on a small library of 15 marine-derived compounds that were isolated from Scleractinia-associated organisms, which have shown the 
Fig. 1 Certain significant events in the history of marine-derived bioactive compounds

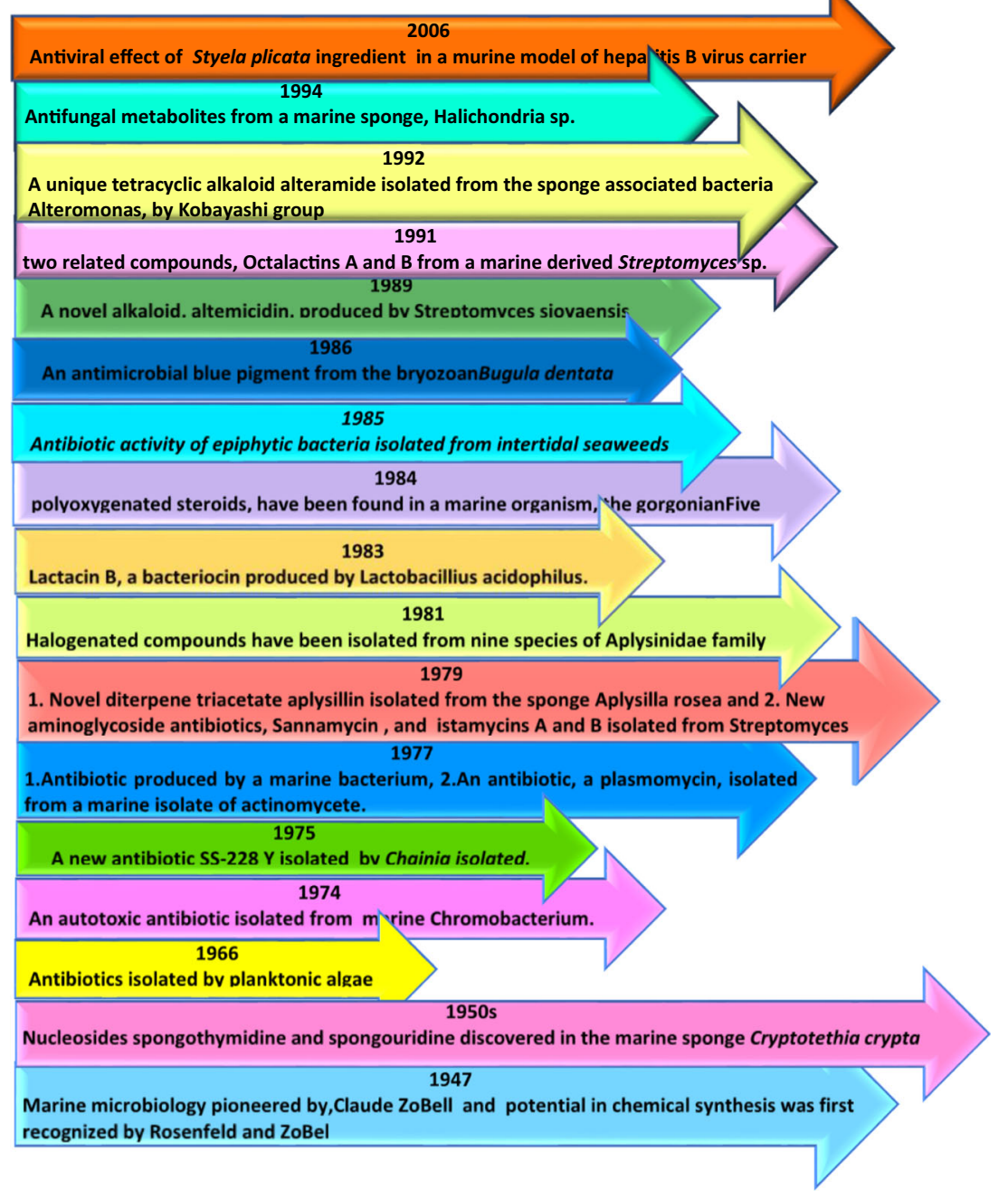

potential of inhibitory actions towards SARS-CoV-2. The selection of naturally occurring compounds from the marinebased products library was based on the ADME analysis to evaluate their physio-chemical properties of the compounds which were later, after molecular docking studies, reported as potential inhibitors of COVID-19 targets (Zahran et al. 2020). Docking was carried out on five target sites of SARS-CoV-2. The first target site is a viral main protease (PDB ID 6LU7). Viral methyltransferase, Nsp16 a nonstructural protein (PDB ID $6 \mathrm{~W} 4 \mathrm{H})$, is a crucial protein because it forms a complex with different protein nsp 10 which leads to methylation at the 2'-O position of viral RNA ribose. With this modification, the virus successfully conceals itself from the host immune system (Lin et al. 2020).

Viral RNA-dependent RNA polymerase (nsp12) (RdRp) is an enzyme that has a crucial function in replication during the viral replication cycle inside the host by forming a complex with nsp7 and nsp8. This class of enzyme is inhibited by Remdesivir in its triphosphate form (PDB ID 7BV2) (Yin et al. 2020).
Another target site, viral spike protein (PDB ID 6M0J), which binds to the receptors present on host cells, assists the entry of the virus into host machinery, and human ACE2, which is the viral recognition protein (PDB ID 6VW1), but these two sites were not able to give good docking scores with selected compounds. Among the selected compounds, Isotirandamycin B, Tirandamycin B, and Tirandamycin A are found to be potential inhibitors against SARS-CoV-2 methyltransferase nsp16/10 and Alteramide A showed inhibition against RdRp (nsp12) (Delgado et al. 2020).

The potential of a small library of 5 marine bioactive compounds inhibitory action against SARS-CoV2 main protease $\left(\mathrm{M}^{\mathrm{PRO}}\right)$ has been investigated. The data was retrieved for the apo form of $\mathrm{M}^{\text {pro }}$ from protein data bank (PDB ID 6M03) and marine-derived bioactive compounds from PubChem; the compounds include 2 MNPs from Petrosia, a species of sponges, from the family Aplysinidae, and one coral species Pterogorgia citrina. The compounds were docked, and those with good docking energy were later on examined by molecular dynamics and simulation studies to check the stability, 
Table 1 Antiviral agents are derived from marine organisms

\begin{tabular}{|c|c|c|c|c|}
\hline Organism & Species & Compound & Biological activity against viruses & Reference \\
\hline Sponges & Tethya cripta & Acyclovir & HSV & Elion et al. 1977 \\
\hline Sponges & Tethya cripta & Ara-A (vidarabine) & HSV & Pde Garilhe et al. 1964 \\
\hline Sponges & Tethya cripta & Ara-C (cytarabine) & HSV & Muller et al. 1985 \\
\hline Sponges & Disidea avara & Avarol & HSV & $\begin{array}{l}\text { Muller et al. } 1987, \\
\text { Horwitz et al. } 1964\end{array}$ \\
\hline Sponges & Tethya cripta & $\begin{array}{l}\text { Azidothymidine } \\
\text { (zidovudine) }\end{array}$ & HSV, HIV & Horwitz et al. 1964 \\
\hline Bacteria & Bacillus licheiformis & EPS-1 & HSV-2 & Arena et al. 2006 \\
\hline Bacteria & Geobacillusthermodenitrificans & EPS-2 & HSV-2 & Arena et al. 2009 \\
\hline Bacteria & Deepsea bacteria & Macrolactin A & HIV, HSV & Gustafson et al. $1989 \mathrm{~b}$ \\
\hline Cyanobacteria & Nostoc ellipsosporum & Cyanovirin-N & HIV-1, HIV-2 & Boyd et al. 1996 \\
\hline Fungi & Fusarium heterosporum & Equistein & HIV-1 & Singh et al. 1998 \\
\hline Fungi & Scytidium sp. & Halovir A-E & $\begin{array}{l}\text { HSV-1 and HSV-2 (destabilization of mem- } \\
\text { brane) }\end{array}$ & Rowley et al. 2003 \\
\hline Fungi & Phoma sp. & Phomasetin & HIV-1 integrase & Singh et al. 1998 \\
\hline Fungi & Fusarium sp. & Sansalvamide A & $\begin{array}{l}\text { MCV relaxation of DNA it is binding, and } \\
\text { complex formation by topoisomerase }\end{array}$ & Hwang et al. 1999 \\
\hline Fungi & Stachybotrys sp. & Stachyflin RF-7260 & H1N1 & $\begin{array}{l}\text { Minagawa et al. } \\
\text { 2002a, 2002b }\end{array}$ \\
\hline Fungi & Aspergillus terreus & Rubrolide S & H1N1 & Zhu et al. 2014 \\
\hline \multirow[t]{2}{*}{ Fungi } & Penicillium chrysogenum & sorbicatechols A & H1N1 & Peng et al. 2014 \\
\hline & Cladosporium sp & Cladosporisteroid B & Anti- $\mathrm{H}_{3} \mathrm{~N}_{2}$ & Pang et al. 2018 \\
\hline Fungi & Penicillium sp. & Trypilepyrazinol & $\mathrm{HIV}$ and $\mathrm{HCV}$ & Li et al. $2019 b$ \\
\hline Fungi & Penicillium raistrickii & $\begin{array}{l}\text { Raistrickindole } \mathrm{A} \text { and } \\
\text { raistrickin }\end{array}$ & Anti-HCV & Li et al. 2019a \\
\hline Fungi & Aspergillus versicolor & $\begin{array}{l}\text { Quinones } \\
\text { (anthraquinones) }\end{array}$ & anti-HSV-1 & Huang et al. 2017 \\
\hline Fungi & Neosartorya udagawae & Neosartoryadins A and B & H1N1 & Yu et al. 2015 \\
\hline Fungi & $\begin{array}{l}\text { Streptomyces koyangensis } \\
\text { SCSIO } 5802\end{array}$ & $\begin{array}{l}\text { Novel Butenolide } \\
\text { derivative }\end{array}$ & Anti-HSV-1 & Huang et al. 2019 \\
\hline Fungi & Simplicillium obclavatum & $\begin{array}{l}\text { Simplicilliumtide } J \text { and } \\
\text { Verlamelins A and B }\end{array}$ & HSV-1 & Liang et al. 2017 \\
\hline Fungi & Aspergillus versicolor & $\begin{array}{l}\text { Aspergilols } \mathrm{H}, \mathrm{I} \text { and } \\
\text { Coccoquinone A }\end{array}$ & HSV-1 & Huang et al. 2017 \\
\hline Fungi & $\begin{array}{l}\text { Acremonium persicinum } \\
\text { SCSIO } 115\end{array}$ & $\begin{array}{l}\text { Acremonpeptides A and } \\
\text { Acremonpeptide D }\end{array}$ & HSV-1 & Luo et al. 2019 \\
\hline Fungi & Penicillium sp. IMB17-046 & Trypilepyrazinol & Anti-HIV and $\mathrm{HCV}$ & Li et al. $2019 b$ \\
\hline Fungi & Cladosporium sp & Pregnane & Anti -RSV & Yu et al. 2018 \\
\hline Sponges & Discodermia calyx & Calceramide A-C & Influenza & Nakao et al. 2001 \\
\hline Sponges & Clathria sp.. & Clathsterol & HIV-1 & Rudi et al. 2001 \\
\hline Sponges & Sidonops microspinosa & Microspinosamide & HIV-1 & Rashid et al. 2001 \\
\hline Sponges & Monanchora sp. & Crambescidin & HIV-1 & Chang et al. 2003 \\
\hline Sponges & Hamigera tarangaensis & Hamigeran B & Herpes and poliovirus & Wellington et al. 2000 \\
\hline Sponges & Hippiospongia metachromatic & Ilimaquinone & $\mathrm{RNase} \mathrm{H}$ function of the reverse transcriptase & Loya and Hizi 1993 \\
\hline Sponges & Neamphius huxleyi & Nemphamide A & HIV-1 CPE & Oku et al. 2004 \\
\hline Sponges & Truncatella angustata & Truncateols $\mathrm{O}$ and $\mathrm{P}$ & Anti -HIV & Zhao et al. 2018 \\
\hline
\end{tabular}

flexibility, and average distance between the compounds and target site for $100 \mathrm{~ns}$ root mean square deviation (RMSD), root mean square fluctuation (RMSF) along with the calculation of a distance matrix. Among them, the (11R)-11-epi-Fistularin-3 belonging to the Family Aplysinidae of molecular formula $\mathrm{C}_{31} \mathrm{H}_{30} \mathrm{Br}_{6} \mathrm{~N}_{4} \mathrm{O}_{11}$ (PubChem ID 11170714) concluded as a 
Fig. 2 The spectrum of biological activity of stony coral-associated organisms

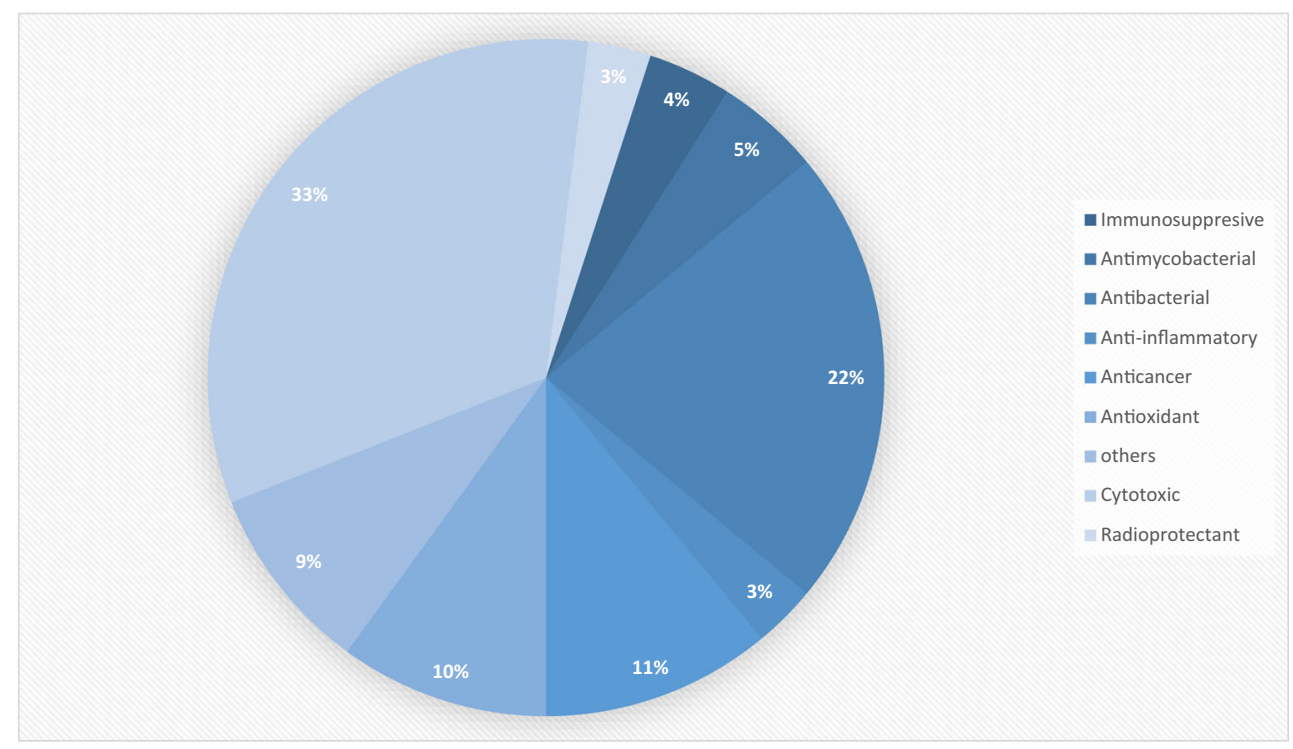

promising inhibitor of COVID-19, exhibiting a good docking score and its interaction with active site forming many hydrophobic interactions and hydrogen bonds (Khan et al. 2020).

Further, Gentile et al. (2020) selected 17 inhibitory molecules against SARS-CoV-2 by performing the virtual screening from the MNP library of 14,064 molecules. The docking and molecular dynamics simulation studies were conducted on the potential inhibitory compounds (Gentile et al. 2020). The selected library of marine natural products contains an enormous number of conformers (164,952 conformers) which are generated from the 14,064 molecules, but only 770 conformers meet the criteria of pharmacophore filter, which is a binding-site derived model. Final filtering was done concerning the co-crystallized N3 ligand which has an RMSD value lower than $2 \AA$ which decreases the library to 197 molecules, molecular docking, and molecular dynamics (MD) simulation studies procedure performed on 180 residual molecules.

The compounds belonging to the chemical category phlorotannins, phloroglucinol (1,3,5-trihydroxy benzene), isolated from brown alga Sargassum frequently found in the species Sargassum spinuligerum found to be more promising inhibitors. The complete process for the isolation of marine microorganisms, characterization of secondary metabolites/ biomolecules, screening of biomolecules, and their potential use by in silico approach and in vitro process and further development of a drug is shown in Fig. 3.

\section{SARS-CoV-2 inhibitors from marine macroalgae}

Marine macroalgae have been investigated by numerous experts as a superb chance to turn into a boundless medium of biologically functional compounds to provide potential therapeutic drugs (Table 3). Both algae and plant-derived active compounds are biodegradable, biocompatible, and safe, yet the creation cost of sulfated polysaccharides produced from algae is lower than the plant-derived bioactive (Ruocco et al. 2016).

Marine-derived sulfated polysaccharides are water soluble and could be separated without much of a stretch utilizing a watery extraction strategy, unlike plant-based extracts that utilize harmful organic compounds. The physio-chemical and mechanical properties of sulfated polysaccharides can effectively be adjusted, which builds its utilization in drug ventures (Lee et al. 2017). The antiviral activity of polysaccharides is well studied and contemplated as one of the most promising choices for the prevention and control of COVID-19 (Mohammed et al. 2021).

Polysaccharides isolated from marine organisms are the most significant and prevalent biological macromolecules available in diverse structures. Despite being a potential source of natural compounds for drug discovery, they are not being utilized well.

The biological activity of sulfated polysaccharides includes inhibition of the viral replication cycle inside the host cell. The mechanism involves hindering the transcription and translation processes of the virus cycle or adjusting the host cell immune response. Although potential inhibition against COVID-19 is shown by both, green growth-based and plantbased mixtures, the two of them have their advantages and disadvantages.

Sulfated polysaccharides, present in the cell walls of marine microbes, are naturally occurring complex polymers. It includes carrageenan and agar isolated from macroalgae, fucoidan, and laminarian produced by brown macroalgae and ulvan from green macroalgae (Wijesekara et al. 2011). 
Table 2 Marine-derived bioactive compounds against SARS-CoV-2 extracted from coral halobiont

\begin{tabular}{|c|c|c|c|c|}
\hline Compound name & Biological activity & Chemical category & Source (microorganism) & Reference \\
\hline Alteramide A & Cytotoxic and antifungal & Tetracyclic alkaloid & Pseudoalteromonas sp & $\begin{array}{l}\text { Shigemori et al. 1992, } \\
\text { Moree et al. } 2014\end{array}$ \\
\hline 1E-Pitiamide B & Antiproliferative & Fatty acid amide & Phormidium corallyticum & Cai et al. 2016 \\
\hline Pitiamide A & Antiproliferative & Fatty acid amide & Phormidium corallyticum & Cai et al. 2016 \\
\hline Aspetritone A & Cytotoxic antibacterial & Anthraquinone derivative & Aspergillus tritici SP2-8-1 & Wang et al. 2017 \\
\hline Tirandamycin B & Antibacterial & Tirandamycin derivative. & Streptomyces sp & Cong et al. 2019 \\
\hline Tirandamycin A & Antibacterial & Tirandamycin derivative & Streptomyces sp & Cong et al. 2019 \\
\hline Isotirandamycin B & Bacteriostatic & Tirandamycin analog. & Streptomyces sp & Cong et al. 2019 \\
\hline F-11334A1 & Cytotoxic antitubercular & Hydroquinone derivative & Gliomastix sp. & Chen, et al. 2020 \\
\hline (2E, 4E)-4'- Dihydrophaseic acid & Not mentioned & Sesquiterpene & Scopulariopsis sp. & Song et al. 2020 \\
\hline Aspetritone B & Cytotoxic antibacterial & Anthraquinone derivative & Aspergillus tritici SP2-8-1 & Wang et al. 2017 \\
\hline Violaceol II & Cytotoxic and antioxidant & Phenyl ether derivative & Scopulariopsis sp. & $\begin{array}{l}\text { Elnaggar et al. } 2016 \\
\text { Liu et al. } 2017\end{array}$ \\
\hline Violaceol I & Cytotoxic and antioxidant & Phenyl ether derivative & Scopulariopsis sp. & $\begin{array}{l}\text { Elnaggar et al. } 2016 \\
\text { Liu et al. } 2017\end{array}$ \\
\hline 13-O-acetylsydowinin B & Antioxidant & Xanthone. Stylophora sp. & Scopulariopsis sp & $\begin{array}{l}\text { Elnaggar et al. } 2016 \\
\text { Liu et al. } 2017\end{array}$ \\
\hline 3-Prenylterphenyllin & Cytotoxic antibacterial & Terphenyllin derivative $G$ & Aspergillus tritici SP2-8-1 & Wang et al. 2017 \\
\hline AGI-B4 & Cytotoxic & Xanthone & Scopulariopsis sp. & Elnaggar et al. 2016 \\
\hline
\end{tabular}
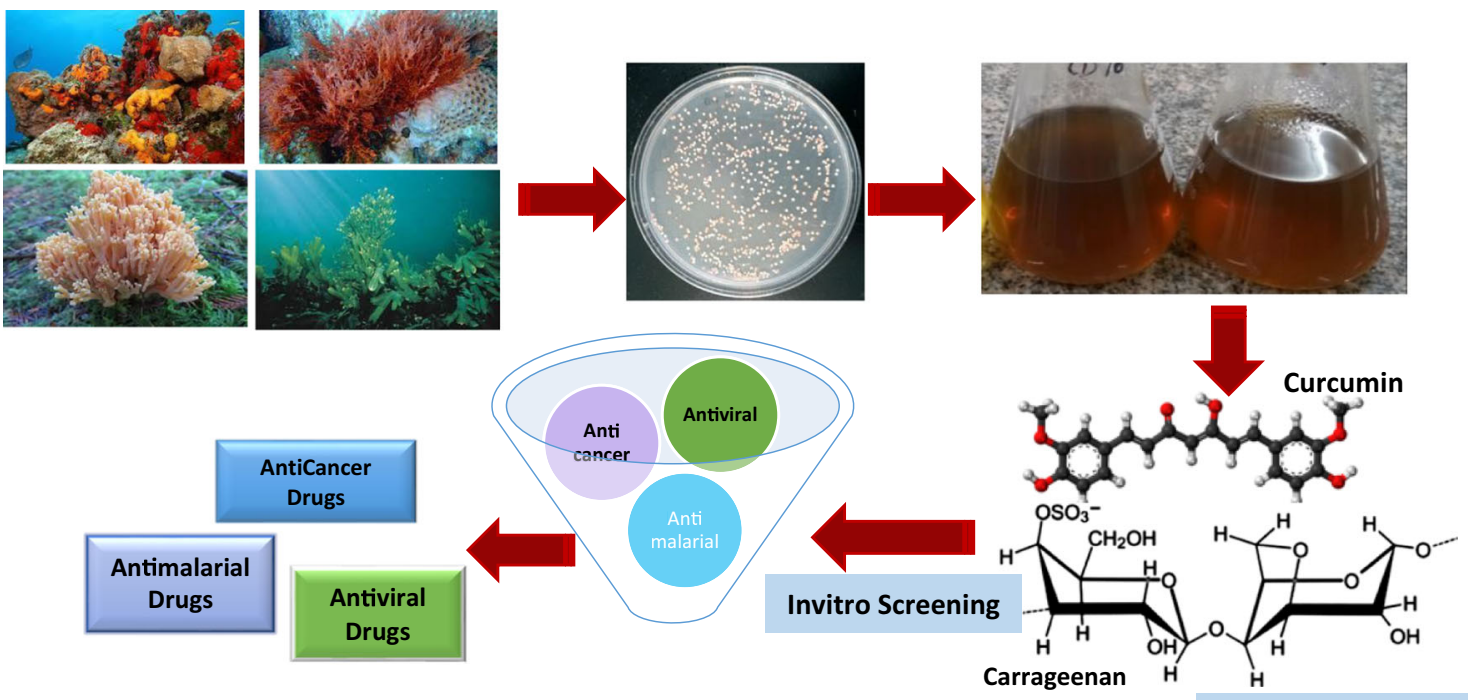

In silico Screening

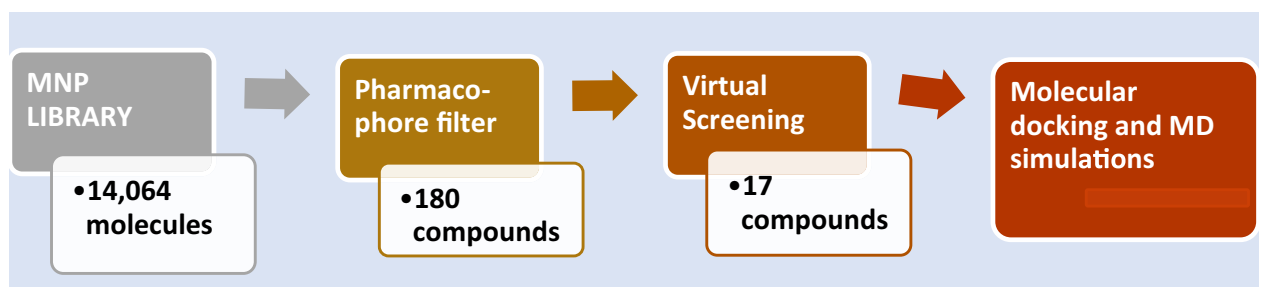

Fig. 3 Schematic representation of the process for isolation of marine microorganisms, characterization of secondary metabolites/biomolecules, screening of biomolecules, and their potential use by in silico approach and in vitro process and further development of drug 
Table 3 Marine-derived sulfated polysaccharides having inhibitory properties against SAR-CoV-2

\begin{tabular}{lll}
\hline Compound name & Mechanism of action & References \\
\hline Iota-carrageenan derived nasal spray & In-vitro inhibition of COVID-19 & Bansal et al. 2020 \\
Carrageenan-derived nasal spray & $2.5 \%$ decrease in recurring symptoms & Koenighofer et al. 2014 \\
Carrageenan and fucoidan & Binds with s-glycoprotein of virus & Song et al. 2020 \\
Iota-carrageenan derived lozenges & S-glycoprotein denaturation & Morokutti-Kurz et al. 2017 \\
Iota-carrageenan and fucoidan kappa carrageenan & Prevention of respiratory tract infections & Grassauer et al. 2008 \\
Iota-carrageenan-derived nasal spray & Upper respiratory tract nasal congestion & Graf et al. 2018 \\
Iota-carrageenan & The increased recovery rate from COVID-19 infection by 2.4-fold & Hemilia et al., 2020 \\
Lambda-carrageenan & Prevents viral attachment to receptors of cell surface & Jang et al. 2020 \\
Fucoidan & Binding of sulfated polysaccharides with s-glycoprotein & Kwon et al. 2020 \\
\hline
\end{tabular}

The antiviral property of sulfated polysaccharides and their uses against the SARS-CoV-2 especially as vaccine adjuvants, nanomaterial, and drug delivery applications have been explored. This study proposed the strategy for polysaccharide capped gold particle vaccine loaded with $\mathrm{S}$ or $\mathrm{N}$ protein, for the therapeutic of SARS-CoV-2 (Chen et al. 2020).

Wang et al., in 2012, suggested that sulfated polysaccharides deter the various stages of the infection cycle of SARSCoV-2 and can provide future drugs against SARS-CoV-2 (Wang et al. 2012). Sulfated polysaccharides were previously reported to prevent infection against other notorious diseases. The sulfated polysaccharides of seaweeds antagonistic nature towards the herpes simplex virus (HSV) (Gomaa and Elshoubaky 2016). Their antiviral activity against HIV-1
(Besednova et al. 2019) and inhibitory action against the chikungunya virus was also demonstrated (Cirne-Santos et al. 2019). Inspired by various researches, the mechanism of action of marine-derived biomolecules against COVID-19 is depicted in Fig. 4.

Sulfated galactans, the major polysaccharide of red algae, consists of linear polymers, and the chain consists of alternating units with 3-linked $\beta$-D-galactopyranose and 4linked $\alpha$-D-galactopyranose. In the sulfated galactan, two major instances were found: carrageenans, which consist of a 4 -linked $\alpha$-galactose fraction with dextro-rotatory (D-) arrangement. Whereas agarans consist of the 4-linked $\alpha$ galactose constituent with levorotatory (L-). The antiviral properties of carrageenan have also been demonstrated with
Fig. 4 Schematic diagram indicating a collection of efficacious anti-SARS-CoV-2 drug; potential candidates derived from marine microorganisms and their possible mode of action for possession of high degree druglikeness for prevention and treatment of COVID-19

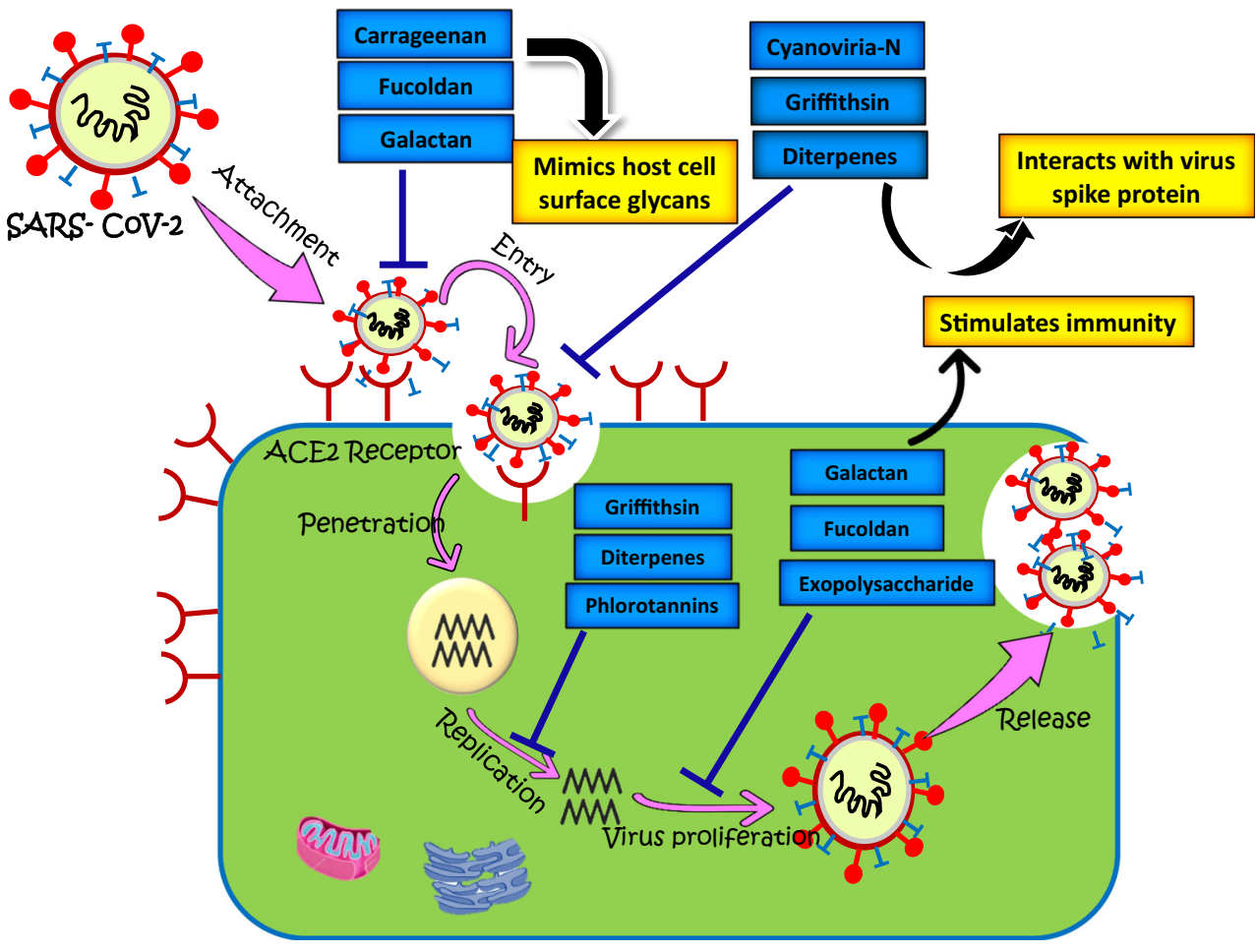


the potential to prevent various viral infections. It can significantly disrupt the association of virus and host cell receptors, hence obstruct the entry of viral particles inside of the cell (Al-Alawi et al. 2011).

Grassauer et al. (2008) explored the impact of carrageenan on the restraint of the cell death due to COVID-19, in Feline kidney cells. Iota-carrageenan, a sulfated polysaccharide derived from seaweed, shows critical resistance at low concentrations $(4 \mu \mathrm{g} / \mathrm{ml})$; however, kappa and lambda-carrageenan were not found adequate. They revealed that the host cell pretreated with the elevated concentration of carrageenan, i.e., $400 \mu \mathrm{g} / \mathrm{ml}$ showed just $35 \%$ suppression. The outcome showed that pre-treatment is not adequate to shield cells from SAR-CoV-2 infection. They proposed carrageenan as an antiviral agent, ought to be available with virus interacting with the host cell at the time of infection. Moreover, it proposes that carrageenan could be covered or inseminated to the strong surface of cleanliness or sterile things like a cotton swab, facial masks, gloves, and tissue paper, etc. (Grassauer et al. 2008; Morokutti-Kurz et al. 2021).

An iota-carrageenan-based nasal spray was also developed, which was found to be efficacious in patients with a common cold, one of the common symptoms of human coronavirus 229E (alpha) and human Covid OC43 (beta). Its administration has shown a decrease of 2.5 -fold in reoccurring symptoms and enhanced viral eviction in comparison to the patients treated under placebo control (Hemilia and Chalker 2020; Koenighofer et al. 2014).

Graf et al., in 2018, developed a nasal spray involving xylometazoline hydrochloride $(0.05 \%)$ and carrageenan $(0.12 \%)$. This combination of these two has been accounted for to assuage nasal blockage in the upper respiratory tract, and at the same time, respiratory mucosa was found to be protected against the virus (Graf et al. 2018).

The lozenges using iota-carrageenan $(10 \mathrm{mg})$ as active drug constituents were developed to treat throat problems brought about by a human Covid OC43. The studies indicated that virus surface protein, glycoproteins, were inactivated at the effective time of lozenge inside the mouth. Due to the low $\mathrm{pH}$ of the mouth, carrageenan-produced lozenges faced the morphological changes of glycoproteins. Denaturation of glycoproteins prompts hindering of viral effects on the host (Morokutti-Kurz et al. 2017). Further, in 2021, the same group reported that the admission of the COVID-19 spike pseudotyped lentivirus can successfully be prevented by the use of iota-carrageenan in a dose-dependent manner. The experiment revealed that $2.6 \mu \mathrm{g} / \mathrm{ml}$ of iota-carrageenan can efficiently neutralize the SARS-CoV-2 spike pseudotyped lentivirus with an $\mathrm{IC}_{50}$ value. The work was supported by similar results against several rhinoviruses and endemic coronaviruses when used as iota-carrageenan containing nasal spray. The overall study suggests that the application of iota- carrageenan may be used as a potent and safe preventive treatment against COVID-19 (Morokutti-Kurz et al. 2021).

Infection of SARS-CoV-2 exerts release of reactive oxygen species release (ROS) due to which the adjoining cells become vulnerable to the virus infection. In such a case, the drugs with antioxidant activity would be a good candidate against SARSCoV-2 infection to maintain redox homeostasis (Morshedul 2019). Some marine algae-derived bioactive compounds have been reported to have strong antioxidant properties. Hence, they may act as shielding against oxidative stress-induced damage. Fucoxanthin, a carotenoid extracted from Sargassum siliquastrum, impeded $\mathrm{H}_{2} \mathrm{O}_{2}$-induced DNA damage by protecting with increased production of GSH level, as well as higher expression of SOD gene (Pangestuti et al. 2013).

The effect of fucosterol was tested on experimental model rats, and it was observed that it was able to increase cellular antioxidant enzymes, such as CAT, SOD, and GPx (Lee et al. 2003). It has also been observed that fucosterol was efficient to inhibit ROS production in tert-butyl hydroperoxide ( $\mathrm{t}$ BHP)-stimulated RAW264.7 cells (Jung et al. 2013). Apart from this, fucosterol showed protection from oxidative stressinduced damage of human hepatic cells, HepG2 cells, by enhancing the level of an intracellular antioxidant, GSH (Choi et al. 2015).

\section{Consideration and challenges}

COVID-19 is an unusual global health threat, and there is no effective drug available to date to deal with the pandemic situation and to reduce the infection rate (Mishra et al. 2020; Alam et al. 2020). In the current pandemic situation, it is of utmost importance to ensure that rigorous and adequate clinical trials have been performed to evaluate the new antiviral drugs to avoid the ineffective and unsafe usage of drugs (Lai et al. 2020). The marine-derived secondary metabolites with diverse new chemical structures have already represented its potential in a variety of fascinating biological activities and immense prospective for the discovery of new therapeutic compounds for drug development to deal with the emerging mutants of COVID-19. The potential feature of novel marine bioactive compounds as anti-inflammatory and antioxidant activity could be used against COVID-19 as these are very potent, efficiently modulates several cell signaling pathways to reduce cytokine release, and activates antioxidant response pathways.

Extensive investigation and the deep analysis of the structural activity of marine bioactive compounds, which have immunomodulatory activities, would prove to be a good option in the treatment of severe COVID-19 infection as compared to chemically synthesized drugs. More confined and focused studies are required to understand the chemical composition 
and structure, biological activity, and mechanisms of action of marine bioactive compounds in pharmaceutical sectors.

Though we have an advanced multi-omics approach that can be used to narrow down the choice of potential bioactive compounds and bioinformatics tools that can help to find the interaction of these molecules with SARS-CoV-2 virus infection (Singh et al. 2021). Through repurposing of drugs is also being studied, but it has shown ineffectiveness. Moreover, the mutation rate of SARS-CoV-2 has raised the concern because previous studies have suggested that mutations in the target proteins of the coronaviruses can be associated with drug resistance (Deng et al. 2014).

The world is still facing the uncertainty of COVID-19 spread and protection against it. The advancement in multiomics technology, studies on gene mutations as well as bioinformatic tools will help to put one step forward in the selection of potential drug candidate to the threat of COVID-19.

Author contribution All authors contributed to the article and approved the submitted version. RS was involved in the designing, conception, and revising of the manuscript critically for intellectual content. NC was involved in drafting the manuscript. MK was involved in critically examining the manuscript and incorporation of important relevant information.

Data Availability NA.

\section{Declarations}

\section{Ethics approval and consent to participate NA.}

Consent for publication NA (as no image has been copied).

Conflict of interest The authors declare no competing interests.

\section{References}

Abdel-Lateff A, Klemke C, König GM, Wright A D (2003) Two new xanthone derivatives from the calcicolous marine fungus wardomyces anomalus. J Nat Prod. 66:706-708 10.102/np020518b

Al-Alawi AA, Al-Marhubi IM, Al-Belushi MSM, Soussi B (2011) Characterization of carrageenan extracted from Hypnea bryoides in Oman. Mar Biotechnol 13:893-899. https://doi.org/10.1007/ s10126-010-9350-7

Alam A, Siddiqui MF, Imam N, Ali R, Mushtaque M, Ishrat R (2020) Covid-19: current knowledge disease potential prevention and clinical advances. Turkish J of bio 44:121-131

Arena A, Gugliandolo C, Stassi G, Pavone B, Iannello D, Bisignano G, Maugeri TL (2009) An exopolysaccharide produced by Geobacillus thermodenitrificans strain B3-72: antiviral activity on immunocompetent cells. Immunol Lett 123:132-137. https://doi.org/10.1016/ jimlet200903001

Arena A, Maugeri TL, Pavone B, Iannello D, Gugliandolo C, Bisignano G (2006) Antiviral and immunomodulatory effect of a novel exopolysaccharide from a marine thermotolerant Bacillus licheniformis. Int Immunopharmacol 6:8-13. https://doi.org/10. 1016/jintimp200507004
Arif JM, Al-Hazzani AA, Kunhi M, Al-Khodairy F (2004) Novel marine compounds: anticancer or genotoxic. J Biomed Biotechnol. https:// doi.org/10.1155/S1110724304307060

Behl T, Kaur I, Bungau S, Kumar A, Sahab Uddin M, Kumar C, Pal G, Sahil SK, Zengin G, Arora S (2020) The dual impact of ACE2 in COVID-19 and ironical actions in geriatrics and pediatrics with possible therapeutic solutions. Life Sci 257:118075. https://doi. org/10.1016/j.lfs.2020.118075

Bansal S, Jonsson CB, Taylor SL, Figueroa JM, Dugour AV, Palacios C, Vega JC (2020) Iota-carrageenan and xylitol inhibit SARS-CoV-2 in cell culture. BioRxiv. https://doi.org/10.1101/20200819225854

Bergmann W Feeney R J (1950) The isolation of a new thymine pentoside from sponges. J Am Chem Soc 72: 2809-2810. https:// doi.org/10.1021/ja01162a543

Bergmann W, Feeney RJ (1951) Contributions to the study of marine products 32: the nucleosides of sponges. I J Org Chem 16:981-987

Besednova NN, Zvyagintseva TN, Kuznetsova TA, Makarenkova ID, Smolina TP, Fedyanina LN, Kryzhanovsky SP, Zaporozhets TS (2019) Marine algae metabolites as promising therapeutics for the prevention and treatment of HIV/AIDS. Metabolites. 9:87. https:// doi.org/10.3390/metabo9050087

Bhatt A, Arora P, Prajapati SK (2020) Can algal derived bioactive metabolites serve as potential therapeutics for the treatment of SARSCoV-2 like viral infection? Front Microbiol 11:2668. https://doi.org/ 10.3389/fmicb2020596374

Boyd MR, Gustafson K, McMahon J, Shoemaker R (1996) Discovery of cyanovirin-N a novel HIV-inactivating protein from Nostoc ellipsosporum that targets viral gp120. Int Conf AIDS 11:71

Cai W, Matthews JH, Paul VJ, Luesch H (2016) Pitiamides a and b multifunctional fatty acid amides from marine cyanobacteria. Planta Med 82:897-902. https://doi.org/10.1055/s-0042-105157

Chang L, Whittaker NF, Bewley CA (2003) Crambesidin 826 and dehyrocrambine A: a new polycyclic guanidine alkaloid from the marine sponge Monanchora sp that inhibit HIV-1 fusion. J Nat Prod 66:1490-1494

Chen X, Han W, Wang G, Zhao (2020) Application prospect of polysaccharides in the development of anti-novel coronavirus drugs and vaccines. Int J Biol Macromol. https://doi.org/10.1016/ jijbiomac202007106

Cirne-Santos CC, Barros CDS, Nogueira CCR, Azevedo RC, Yamomoto KA, Meira GLS et al (2019) Inhibition by marine algae of chikungunya virus isolated from patients in a recent disease outbreak in Rio de Janeiro. Front Microbiol 10:2426. https://doi.org/ 10.3389/fmicb201902426

Cong Z, Huang X, Liu Y, Liu Y, Wang P, Liao S, Yang B, Zhou X, Huang D, Wang J (2019) Cytotoxic anthracycline and antibacterial tirandamycin analogues from a marine-derived Streptomyces sp SCSIO 41399. J Antibiot 72:45-49. https://doi.org/10.1038/ s41429-018-0103-6

Daferner M, Anke T, Sterner O (2002) Zopfiellamides A and B antimicrobial pyrrolidinone derivatives from the marine fungus Zopfiella latipes. Tetrahedron. 58:7781-7784. https://doi.org/10.1016/S00404020(02)00942-0

Delgado BJ, Hernandez-Alias X, Cianferoni D, Serrano L (2020) In silico mutagenesis of human ACE2 with $\mathrm{S}$ protein and translational efficiency explain SARS-CoV-2 infectivity in different species. PLoS Comput Biol. 16 12-e1008450. https://doi.org/10.1371/ journalpcbi1008450

Deng X, StJohn S E, Osswald H L, O’Brien A, Banach B S, Sleeman K. et al. (2014) Coronavirus resistant to a 3C-like protease inhibitor are attenuated for replication and pathogenesis revealing a low genetic barrier but high fitness cost of resistance. J Virol. 88:11886-11898. https://doi.org/10.1128/JVI01528-14

Duarte K, Rocha-Santos TA, Freitas AC, Duarte AC (2012) Analytical techniques for the discovery of bioactive compounds from marine 
fungi. Trends Anal Chem 34:97-110. https://doi.org/10.1016/ jtrac201110014

Elion GB, Furman PA, Fyfe JA, de Miranda P, Beauchamp L, Schaeffer HJ (1977) Selectivity of action of an antiherpetic agent 9-(2-hydroxy ethoxy methyl) guanine. Proc Natl Acad Sci U S A 74:5716-5720

Elnaggar MS, Ebada SS, Ashour ML, Ebrahim W, Müller WE, Mándi A et al (2016) Xanthones and sesquiterpene derivatives from a marine derived fungus Scopulariopsis sp. Tetrahedron. 72:2411-2419. https://doi.org/10.1016/jtet201603073

Gallo ML, Seldes AM, Cabrera GM (2004) Antibiotic long-chain and $\alpha$ $\beta$-unsaturated aldehydes from the culture of the marine fungus Cladosporium sp. Biochem Syst Ecol 32:545-551. https://doi.org/ 10.1016/jbse200308009

Gautschi JT, Amagata T, Amagata A, Valeriote FA (2004) Mooberry S L Crews P Expanding the strategies in natural product studies of marine-derived fungi: a chemical investigation of Penicillium obtained from deep water sediment. J Nat Prod 67:362-367. https:// doi.org/10.1021/np030388m

Gentile D, Patamia V, Scala A, Sciortino MT, Piperno A, Rescifina A (2020) Putative inhibitors of SARS-CoV-2 main protease from a library of marine natural products: a virtual screening and molecular modeling study.Mar Drugs. 18:225. https://doi.org/10.3390/ md18040225

Gomaa HH, Elshoubaky GA (2016) Antiviral activity of sulfated polysaccharides carrageenan from some marine seaweeds. Int J Curr Pharm Rev Res 7:34-42

Gorbalenya AE, Baker SC, Baric R, Groot RJD, Drosten C, Gulyaeva AA, Haagmans BL et al (2020) Severe acute respiratory syndromerelated coronavirus: the species and its viruses - a statement of the Coronavirus Study Group. BioRxiv. https://doi.org/10.1101/ 20200207937862

Graf C, Bernkop-Schnürch A, Egyed A, Koller C, Prieschl-Grassauer E, MorokuttiKurz M (2018) Development of a nasal spray containing xylometazoline hydrochloride and iota-carrageenan for the symptomatic relief of nasal congestion caused by rhinitis and sinusitis. Int J Gen Med 11:275. https://doi.org/10.2147/IJGMS167123

Grassauer A, Weinmuellner R, Meier C, Pretsch A, Prieschl-Grassauer E, Unger $H$ (2008) Iota-carrageenan is a potent inhibitor of rhinovirus infection. Virol J 5:107. https://doi.org/10.1186/1743-422X-5-107

Gustafson KR, Cardellina JH, Fuller RW, Weislow OS, Kiser RF, Snader KM, Patterson GM, Boyd MR (1989a) AIDS - antiviral sulfolipids from cyanobacteria (blue-green algae). J Natl Cancer Inst 81:12541258. https://doi.org/10.1093/jnci/81161254

Hart C (1999) Forged in St Anthony's fire: drugs for migraine. Mod Drug Disc 2:20-21

Hemilia H, Chalker E (2020) Carrageenan nasal spray may double the rate of recovery from coronavirus and influenza virus infections: reanalysis of randomized trial data. https://doi.org/10.21203/rs3rs$108775 / \mathrm{v} 1$

Horwitz J P, Chua J, Noel M (1964) The monomesylates of 1-(2 -deoxyd-lyxofuranosyl)thymidine. J Org Chem. 29:2076-2078. https://doi. org/10.1021/jo01030a546 http://www niaid nih gov/diseasesconditions/covid-19

Huang H, Song Y, Zang R, Wang X, Ju J (2019) Octyl substituted butenolides from marine-derived Streptomyces koyangensi. Nat Prod Res.1:6. https://doi.org/10.1080/1478641920191686368

Huang Z, Nong X, Ren Z, Wang J, Zhang X, Qi S (2017) Anti-HSV-1 antioxidant and antifouling phenolic compounds from the deep-seaderived fungus Aspergillus versicolor SCSIO 41502. Bioorg Med Chem Lett 27:787-791. https://doi.org/10.1016/jbmcl201701032

Hwang Y, Rowley D, Rhodes D, Gertsch J, Fenical W, Bushman F (1999) Mechanism of inhibition of a poxvirus topoisomerase by the marine natural product sansalvamide A. Mol Pharmacol 55: 1049-1053. https://doi.org/10.1124/mol5561049

Choi JE, Han YR, Byeon JS, Choung S-Y, Sohn HS, Jung HA (2015) Protective effect of fucosterol isolated from the edible brown algae
Ecklonia stolonifera and Eisenia bicyclis on tert-butyl hydroperoxide- and tacrine-induced HepG2 cell injury. J Pharmacokinet Pharmacodyn 67:1170-1178. https://doi.org/10. 1111/jphp12404

Jang YJ, Shin H, Lee MK, Kwon OS, Shin JS, Kim Y, Kim M (2020) Antiviral activity of lambda-carrageenan against influenza viruses in mice and severe acute respiratory syndrome coronavirus 2 in vitro. BioRxiv. https://doi.org/10.1101/20200823.255364

Jung H A, Jin S E, Ahn B R, Lee C M, Choi J S (2013) Antiinflammatory activity of edible brown alga Eisenia bicyclis and its constituents fucosterol and phlorotannins in LPS-stimulated RAW264 7 macrophages. Food and Chem Toxicol. 59:199-206. 10.1016/j fct 201305061

Khan MT, Ali A, Wang Q, Irfan M, Khan A, Zeb MT, Zhang Y-J, Chinnasamy S, Wei D-Q (2020) Marine natural compounds as potents inhibitors against the main protease of SARS-CoV-2 - a molecular dynamic study. J Biomol Struct Dyn 1:11. https://doi.org/10. 1080/0739110220201769733

Koenighofer M, Lion T, Bodenteich A, Prieschl-Grassauer E, Grassauer A, Unger H, Mueller C A, Fazekas T (2014) Carrageenan nasal spray in virus confirmed common cold: individual patient data analysis of two randomized controlled trials. Multidiscip Respir Med. 9: 57. https://doi.org/10.1186/2049-6958-9-57

Kwon PS, Oh H, Kwon SJ, Jin W, Zhang F, Fraser K, Hong JJ et al (2020) Sulfated polysaccharides effectively inhibit SARS-CoV-2 in vitro. Cell Discov 6:1-4. https://doi.org/10.1038/s41421-02000192-8

Lai CC, Shih TP, Ko WC, Tang HJ, Hsueh PR (2020) Severe acute respiratory syndrome coronavirus 2 (SARS-CoV-2) and coronavirus disease-2019 (COVID-19): The epidemic and the challenges. Int J Antimicrob Agents 55(3):105924. https://doi.org/10.1016/j. ijantimicag.2020.105924

Lee S, Lee YS, Jung SH et al (2003) Anti-oxidant activities of fucosterol from the marine algae Pelvetia siliquosa. Arch Pharm ResI 26:719 722. https://doi.org/10.1007/BF02976680

Lee YE, Kim H, Seo C, Park T, Lee KB, Yoo SY, Hong SC, Kim JT, Lee J (2017) Marine polysaccharides: therapeutic efficacy and biomedical applications. Arch Pharm Res 40:1006-1020. https://doi.org/10. 1007/s12272-017-0958-2

Li J, Hu Y, Hao X, Tan J, Li F, Qiao X, Chen S, Xiao C, Chen M, Peng Z, Gan M (2019a) Raistrickindole A an anti-HCV oxazinoindole alkaloid from Penicillium raistrickii IMB17-034. J Nat Prod 82:13911395. https://doi.org/10.1021/acsjnatprod9b00259

Li J, Wang Y, Hao X, Li S, Jia J, Guan Y, Peng Z, Bi H, Xiao C, Cen S, Gan M (2019b) Broad-spectrum antiviral natural products from the marine-derived Penicillium sp IMB17-046. Molecules. 24:28212831. https://doi.org/10.3390/molecules24152821

Liang X, Nong X, Huang Z, Qi S (2017) Antifungal and antiviral cyclic peptides from the deep-sea-derived fungus Simplicillium obclavatum EIODSF 020. J Agric Food Chem 65:5114-5121. https://doi.org/10.1021/acsjafc7b01238

Lin S, Chen H, Ye F, Chen Z, Yang F, Zheng Y, Cao Y, Qiao J et al (2020) Crystal structure of SARS-CoV-2 nsp10/nsp16 20-Omethylase and its implication on antiviral drug design. Signal Transduct Target Ther 5:1-4. https://doi.org/10.1038/s41392-02000241-4

Liu S, Wang H, Su M, Hwang GJ, Hong J, Jung J (2017) New metabolites from the sponge-derived fungus Aspergillus sydowii J05B-7F4. Nat Prod Res 31:1682-1686. https://doi.org/10.1080/ 1478641920171289205

Loya S, Hizi A (1993) The interaction of illimaquinone a selective inhibitor of the RNase $\mathrm{H}$ activity with the reverse transcriptases of human immunodeficiency and murine leukemia retroviruses. J Biol Chem 268:9323-9328. https://doi.org/10.1016/S0021-9258(18)98353-5

Luo M, Zang R, Wang X, Chen Z, Song X, Ju J, Huang H (2019) Natural hydroxamate-containing siderophore acremonpeptides A-D and an 
aluminum complex of acremonpeptide D from the marine-derived Acremonium persicinum SCSIO 115. J Nat Prod 82:2594-2600. https://doi.org/10.1021/acsjnatprod9b00545

Minagawa K, Kouzuki S, Kamigauchi T (2002b) Stachyflin and acetylstachyflin novel anti-influenza A virus substances produced by Stachybotrys sp RF-7260 II Synthesis and preliminary structure-activity relationships of stachyflin derivatives. J Antibiot (Tokyo) 55:165-171. https://doi.org/10.7164/antibiotics55165

Minagawa K, Kouzuki S, Yoshimoto J, Kawamura Y, Tani H, Iwata T, Terui Y, Nakai H, Yagi S, Hattori N et al (2002a) Stachyflin and acetylstachyflin novel anti-influenza A virus substances produced by Stachybotrys sp RF-7260 I Isolation structure elucidation and biological activities. J Antibiot (Tokyo) 55:155-164. https://doi. org/10.7164/antibiotics55155

Mishra BK, Keshari YS, Rao YS, Mishra BK, Mahato B, Ayesha S et al (2020) COVID-19 created chaos across the globe: three novel quarantine epidemic models. Chaos Solitons and Fractals. 138: Article 109928. https://doi.org/10.1016/jchaos2020109928

Mohammed A S A, Naveed M, Jost N (2021) Polysaccharides; classification chemical properties and future perspective applications in fields of pharmacology and biological medicine (a review of current applications and upcoming potentialities). J Polym Environ. https:// doi.org/10.1007/s10924-021-02052-2

Moree W J, McConnell O J, Nguyen D D, Sanchez L M, Yang Y -L, Zhao X, Liu W - T, et al (2014) Microbiota of healthy corals are active against fungi in a light-dependent manner. ACS Chem Biol 9: 2300-2308. https://doi.org/10.1021/cb500432j

Morokutti-Kurz M, Fröba M, Graf P, Große M, Grassauer A, Auth J, Ulrich Schubert U (2021) Iota-carrageenan neutralizes SARS-CoV2 and inhibits viral replication in vitro. Plos One. 16: e0237480. https://doi.org/10.1371/journalpone0237480

Morokutti-Kurz M, Graf C, Prieschl-Grassauer E (2017) Amylmetacresol/2 4-dichlorobenzyl alcohol hexylresorcinol or carrageenan lozenges as active treatments for sore throat. Int J Gen Med.10:53. https://doi.org/10.2147/IJGMS120665

Morshedul A (2019) Essence of antioxidants in aging science: NRF2 a true fact. CPQ Medicine 5:01-05

Muller WEG, Maidhof A, Zahn RK, Schroder HC, Gasic MJ, Heidemann D, Bernd A, Kurelec B (1985) Influence of the antileukemic activity of the novel cytostatic agent avarone and its analogues in vitro and in vivo. Cancer Res 45:4822-4826

Muller WEG, Sobel C, Diehl-Seifert B, Maidhof A, Schroder HC (1987) Influence of the antileukemic and anti-human immunodeficiency virus agent avarol on selected immune responses in vitro and in vivo. Biochem Pharmacol 36:1489-1494

Nakao Y, Takada K, Matsunaga S, Fusetani N (2001) Calyceramides A$\mathrm{C}$ : neuraminidase inhibitory sulfated ceramides from the marine sponge Discodermia calyx. Tetrahydron. 57:3013-3017. https:// doi.org/10.1016/S0040-4020(01)00163-6

Oku N, Gustafson K R, Cartner L K, Wilson J A, Shigematsu N, Hess S, Pannell L K, Boyd M R, McMahon J B (2004) Neamphamide A a new HIV-inhibitory depsipeptide from the Papua New Guinea marine sponge Neamphius huxleyi. J Nat Prod. 67:1407-1411. https:// doi.org/10.1021/np040003f

Pang X, Lin X, Wang J, Liang R, Tian Y, Salendra L, Tu Z (2018) Three new highly oxygenated sterols and one new dihydroisocoumarin from the marine sponge-derived fungus Cladosporium sp SCSIO41007. Steroids. 129:41-46. https://doi.org/10.1016/ jsteroids201712001

Pangestuti R, Vo T-S, Ngo D-H, Kim S-K (2013) Fucoxanthin ameliorates inflammation and oxidative responses in microglia. J Agric Food Chem 61:3876-3883. https://doi.org/10.1021/jf400015k

Peng J, Zhang X, Du L, Wang W, Zhu T, Gu Q, Li D (2014) Sorbicatechols A and B antiviral sorbicillinoids from the marinederived fungus Penicillium chrysogenum PJX-17. J Nat Prod 77: 424-428. https://doi.org/10.1021/np400977e
Rashid MA, Gustafson KR, Cartner LK, Shigematsu N, Pannell LK, Boyd MR (2001) Microspinosamide a new HIV-inhibitory cyclic depsipeptide from the marine sponge Sidonops microspinosa. J Nat Prod 64:117-121. https://doi.org/10.1021/np0002379

Rowley DC, Kelly S, Kauffman CA, Jensen PR, Fenical W (2003) Halovirs A-E new antiviral agents from a marine-derived fungus of the genus Scytalidium. Bioorg Med Chem 11:4263-4274. https://doi.org/10.1016/S0968-0896(03)00395-X

Rudi A, Yosief T, Loya S, Hizi A, Schleyer M, Kashman Y (2001) Clathsterol a novel anti-HIV-1 RT sulfated sterol from the sponge Clathria species. J Nat Prod 64:1451-1453. https://doi.org/10.1021/ $\mathrm{np} 010121 \mathrm{~s}$

Ruocco N, Costantini S, Guariniello S, Costantini M (2016) Polysaccharides from the marine environment with pharmacological cosmeceutical and nutraceutical potential. Molecules.21:551. https://doi.org/10.3390/molecules21050551

Shigemori H, Bae MA, Yazawa K, Sasaki T, Kobayashi JA (1992) Alteramide A a new tetracyclic alkaloid from a bacterium Alteromonas sp associated with the marine sponge Halichondria okadai. J Organomet Chem 57:4317-4320. https://doi.org/10. 1021/jo00041a053

Singh R, Singh PK, Kumar R, Kabir MT, Kamal MA, Rauf A, Albadrani GM et al (2021) Multi-omics approach in the identification of potential therapeutic biomolecule for COVID-19. Front Pharmacol 12: 652335. https://doi.org/10.3389/fphar2021652335

Singh SB, Zink DL, Goetz MA, Dombrowski AW, Polishook JD, Hazuda DJ (1998) Equisetin and a novel opposite stereochemical homolog Phomasetin two fungal metabolites as inhibitors of HIV-1 integrase. Tetrahedron. 39:2243-2246. https://doi.org/10.1016/ S0040-4039(98)00269-X

Sipkema D, Franssen MC, Osinga R, Tramper J, Wijffels RH (2005) Marine sponges as pharmacy. Mar Biotechnol 7:142-162. https:// doi.org/10.1007/s10126-004-0405-5

Song S, Peng H, Wang Q, Liu Z, Dong X, Wen C, Ai C, Zhang Y, Wang Z, Zhu B (2020) Inhibitory activities of marine sulfated polysaccharides against SARSCoV-2. Food Funct 11:7415-7420. https://doi. org/10.1039/D0FO02017F

Tziveleka L-A, Vagias C, Roussis V (2003) Natural products with antiHIV activity from marine organisms. Curr Top Med Chem 3:15121535. https://doi.org/10.2174/1568026033451790

Vincent P, Pignet P, Talmont F, Bozzi L, Fournet B, Guezennec J, Jeanthon C, Prieur D (1994) Production and characterization of an exopolysaccharide excreted by a deep sea hydrothermal vent bacterium isolated from the Polychaete Annelid Alvinella pompejana. Appl Environ Microbiol 60:4134-4141

Wang W, Wang SX, Guan HS (2012) The antiviral activities and mechanisms of marine polysaccharides: an overview. Mar Drugs 10: 2795-2816. https://doi.org/10.3390/md10122795

Wang W, Liao Y, Tang C, Huang X, Luo Z, Chen J, Cai P (2017) Cytotoxic and antibacterial compounds from the coral-derived fungus Aspergillus tritici SP2-8-1. Mar Drugs 15:348. https://doi.org/ $10.3390 / \mathrm{md} 15110348$

Wellington KD, Cambie RC, Rutledge PS, Bergquist PR (2000) Chemistry of sponges 19: novel bioactive metabolites from Hamigera tarangaensis. J Nat Prod 63:79-85. https://doi.org/10. 1021/np9903494

Wijesekara I, Pangestuti R, Kim SK (2011) Biological activities and potential health benefits of sulfated polysaccharides derived from marine algae. Carbohydr Polym 84:14-21. https://doi.org/10.1016/ jcarbpol201010062

Woo PC, Huang Y, Lau SK, Yuen KY (2010) Coronavirus genomics and bioinformatics. Analysis Viruses 2:1804-1820. https://doi.org/10. 3390/v2081803

Xu X, Chen P, Wang J, Feng J, Zhou H, Li X, Zhong W, Hao P (2020) Evolution of the novel coronavirus from the ongoing Wuhan outbreak and modeling of its spike protein for risk of human 
transmission. Sci China Life Sci 63:457-460. https://doi.org/10. 1007/s11427-020-1637-5

Yin W, Mao C, Luan X, Shen D-D, Shen Q, Su H, Wang X et al (2020) Structural basis for inhibition of the RNA-dependent rna polymerase from SARS-CoV-2 by remdesivir. Science. 368:1499-1504. https:// doi.org/10.1126/scienceabc1560

Yu G, Zhou G, Zhu M, Wang W, Zhu T, Gu Q, Li D (2015) Neosartoryadins A and B fumiquinazoline alkaloids from a mangrove-derived fungus Neosartorya udagawae HDN13-313. Org Lett 18:244-247. https://doi.org/10.1021/acsorglett5b02964

Yu M, Guan F, Cao F, Jia Y, Wang C (2018) A new antiviral pregnane from a gorgonian-derived Cladosporium sp Fungus. Nat Prod Res 32:1260-1266. https://doi.org/10.1080/1478641920171342086

Zahran E M, Amgad A, Amira K, Ibrahim A H, Ahamed H A, El-Hossary E M et al (2020) Bioactivity potential of marine natural products from scleractinia-associated microbes and in silico anti-SARSCOV-2 evaluation. Mar Drugs. 18:645. https://doi.org/10.3390/ md18120645
Zhao Y, Liu D, Proksch P, Zhou D, Lin W (2018) Truncateols O-V further isoprenylated cyclohexanols from the sponge-associated fungus Truncatella angustata with antiviral activities. Phytochemistry. 155:61-68. https://doi.org/10.1016/jphytochem201807017

Zhu N, Zhang D, Wang W, Li X, Yang B, Song J, Zhao X, Huang B et al (2020) A novel coronavirus from patients with pneumonia in China 2019. N Engl J Med 382:727-733. https://doi.org/10.1056/ NEJMoa2001017

Zhu T, Chen Z, Liu P, Wang Y, Xin Z, Zhu W (2014) New rubrolides from the marine-derived fungus Aspergillus terreus OUCMDZ1925. J Antibiot 67:315-318. https://doi.org/10.1038/ja2013135

Zumla AW, Chan JF, Azhar EIC, Hui DS et al (2016) Coronavirusesdrug discovery and therapeutic options. Nat Rev Drug Discov 15: 327-347. https://doi.org/10.1038/nrd201537

Publisher's note Springer Nature remains neutral with regard to jurisdictional claims in published maps and institutional affiliations. 